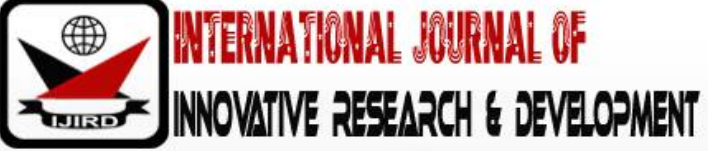

ISSN 2278 - 0211 (Online)

\section{Factor Analysis: Empirical Evidence with Employee Turnover Decision of Tourism Sector}

\author{
S. Damayanthi Edirisinghe \\ Senior Lecturer, Department of Commerce \& Financial Management, University of Kelaniya, Sri Lanka
}

\begin{abstract}
:
The main objective of this paper is to analyze the data and present the information that was gathered from the main survey of this study by using the suitable statistical method. Chosen suitable statistical method in this study was factor analysis. In line to the objectives, researcher initially described descriptive measures briefly and contributed the main attention on interpretation of factor analysis with empirical evidences of Turnover decision of employees engage in the field of Hotel \& Travel sector in Tourism. Objective of run the factor analysis is to simplify data to reduce the number of variables as facilitate to fit a regression model. Before selecting the variables, convergent validity test was run to identify the latent variable correlates by using KMO and Bartlett's test of sphericity and Cronbach Alpha. These tests were significant at $5 \%$ level of significance. When the test was conducted it was observed that the third and fourth questions from Remunerations related scale measuring and the third question of Career related scale measuring were grouped individually. Therefore, rotation solution and extraction method of Principle Component analysis method was used in this study further. After used the rotation method researcher used Regression Analysis to fit the model.
\end{abstract}

Keywords: Factor analysis, employee turnover, hotel and travel sector, convergent validity

\section{Introduction}

Tourism is a dynamic economic sector which plays a significant role in the sustainable economic development and in poverty reduction. Impact of globalization on tourism industry is currently important for several reasons andit is considered as one of the largest and fastest developing sectors of the world. Its high growth and development bring considerable volumes of the foreign currency inflows, infrastructure development, and employment generationetc. And also, tourism has identified as one of the most effective means of job creation and drive economic development in local communities. Further, tourism not only contributes to wealth creation but also increases the access to essential services such as water, sanitation, telecommunications and transportation development. Tourism employment can be classified at two separate levels depending on their participation or contribution to tourism supply-side. In hotel \& travel sector front offices in hotels, restaurants, travel agencies, tourism information offices, aircrafts, cruise lines, resorts or shopping outlets provide direct employment because their employees are in contact with tourists and cater for tourist demand. And also supports indirect employment in activities like restaurant suppliers, construction companies that build and maintain tourist facilities, as well as necessary infrastructure, aircraft manufacturers, various handicrafts producers, marketing agencies, accounting services. Therefore, this study focuses on factors affecting sales employee turnover specifically in travel agent and operators in the tourism sector in Sri Lanka.

\subsection{Problem Identification}

Employee turnover is a problem faced by most organization and it is highly researchable topic in the current context. Although the rate of employee turnover is different from one location or sector to another it is relatively high in hotel \& tourism sector. Some researcher is stated that the voluntary turnover occurs in unpredictable frequencies, while it is mostly amongst staff occupied at operational levels (Milman, 2003)

Turnover intentions refer to one's behavioral attitude to leave an organization, while turnover describes the actual act in detaching oneself from an organization (Armstrong,2009, Allen, et al, 2010)). Moreover, turnover can be understood as the inflow and outflow of employees of a business entity and is considered one of the most important organizational phenomena, because it requires the management to understand, analyze, evaluate and handle its costs (Edirisnghe, 2019).

\subsection{Objectives of the Study}

This is an emerging concept in the developing countries. This study contributes conceptually and empirically to the existing literature as studies regarding these factors have not so far been conducted in this context in Sri Lanka. Therefore, the main objective of this paper is to use suitable test to analyze the data and present the information that was 
gathered from the main survey. Therefore, the following sub objectives were considered.

- Conducting a factor analysis and to measure relationship of each identified factor on employee turnover decision

- Testing of normality, validation of measurement properties and hypothesis

\subsection{Hypothesis of the Study}

- H1a There is no relationship between Remuneration and the sales employee turnover decision

- H2a There is no relationship between career development and the sales employee turnover

- H3a There is no relationship between working environment and the sale employee turnover

- H4a There is no relationship between Job Satisfaction and the sales employee turnover decision

- H4b There is a relationship between Job Satisfaction and the sales employee turnover decision.

\subsection{Conceptual Framework of the Study}

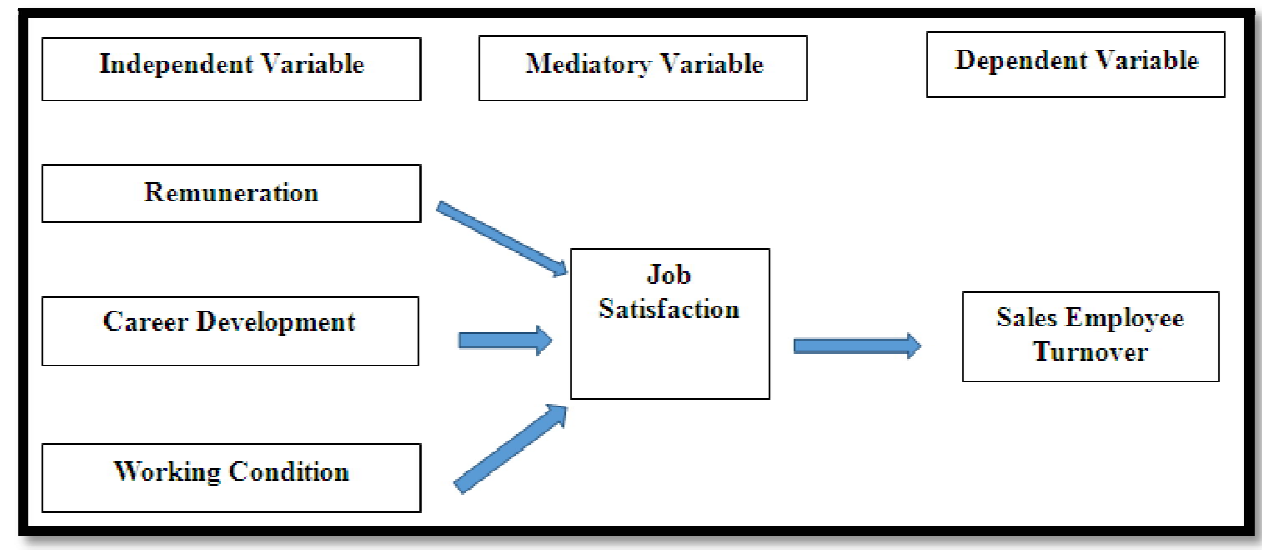

Figure 1: Conceptual Framework of the Study

\subsection{Rationalization of Conceptual Framework}

The conceptual framework for this study was developed by the researcher utilizing literature and evidence acquired with respect of the research problem. This section of the research shows the reasoning and rationale behind the determination of the elements that involve the final type of the conceptual framework that was graphically portrayed above.

This study is to determine the factors that affect sales employee turnover, Travel agents and operators in Hotel Industry. The conceptual framework developed by the author comprises of three independent variables, one mediatory variable and a dependent variable as above. The three independent variables of this study are the Remuneration, Career development and Working environment which were derived from reviewed literature and are considered as major drivers of "Sales Employee turnover decision" (Edirisnghe \& Manuel,2019).

\section{Literature Review}

Though the related literature was published to this study (Edirisnghe \& Manuel, 2019) by considering the completeness of this paper researcher describes some essential parts of the literature as below.

\subsection{Definition of Variables}

\subsubsection{Employee Turnover}

The subject of employee turnover is a critical problem organization have dealt with for a long time (Fathima, et al, 2012,Glebbeek et al. 2004)he initial topics studying turnover primarily focused on "rates of departure" and "stability of employment" which began in the beginning of the twentieth century and employee turnover is investigated ever since then.

In this dynamic environment, employees are an important asset to every company, business and organization. In fact, the success of every company or business is entirely dependent on the effectiveness of its workforce (Samuel and Chipunza, 2009). A business may invest a lot of resources into its core operations and activities, but without a highly effective human resource, success in the long run cannot be achieved (Ton and Huckman, 2008). Thus, when human capital leaves the organization, it is necessary to identify the reasons of turnover because of the importance of retaining better talents and due to the incomparable contribution human capital.

In this competitive and people-oriented business environment representing the modern travel agency and operators in hotel industry, frontline employee such as sales staff performance represents a crucial component of service (Yang, 2010). However, retaining such professionals is a permanent challenge in this segment.

Hence employee turnover is usually not an immediate decision but a process that accumulates over time. Many employees become disconnected from work long before they leave, and these employees have negative effects on the organization resulting in lowering of organizational commitment, absenteeism increases, productivity lowered(Darcy et al 2012, Das\& Baruah, 2013). 


\subsubsection{Remuneration}

According to the scholars Heneman and Schwab (1985) remuneration level refers to the individual's current direct wage or salary. Studies of hotel employees, Lee et al. (2006) stated "service reward and pay has a potential influence on job satisfaction and the commitment employee possess" In the studies by Dwyer et al. (1987) and Jones (1986), better pay leads to higher job satisfaction ultimately resulting reducing employee turnover.

\subsubsection{Work Environment}

Work environment refers to the working conditions in which employees have to perform their duties. These conditions include work schedules, reporting times, nature of supervisors, nature of work, and work flexibility among others (Lee et al ,2015).

\subsection{Career Development}

Scholars revealed that Career development involves creating opportunity for promotion within an organization by providing opportunity for training and skills development that allows employees to improve their employability in the market. As per the adapted Career development scale, it is a measure of the degree to which is proactively developing his or her career as expressed by diverse career behaviors (Gberevbie, 2010,Heavey,et al. (2013).

\subsection{Mediatory Variable - Job Satisfaction}

Job satisfaction is defined as any environmental, psychological combination which affect an employee to consider his job as a gift. It can also be conceptualized as "the pleasurable emotional state resulting from the appraisal of one's job as achieving or facilitating the achievement of one's job values (Kokt, and Ramarumo, ,2015,Locke, 1969, Ongori, H. 2007)).Work satisfaction can be assessed within a particular organizational context, but it can also be used as a measure of one's satisfaction with a particular career.

\subsubsection{Dependent Variable - Employee Turnover}

Literature stated that as the Employee turnover as the proportion of employees who leave an organization over a set period (often on a year basis), expressed as a percentage of total workforce numbers. Turnover intention has been defined as the conscious and deliberate leave an organization. Turnover can also be understood as the inflow and outflow of employees of a business entity (Medina, E, 2012,Mehmood N. et al., 2012,Ruchi et al., 2014)

\section{Methodology}

This research is Quantitative deductive in nature (Edirisinghe, 2019)

\subsection{Population}

The population of this study was considered as sales employees working in Hotel Industry in Sri Lanka

\subsection{Sample and Sampling Method}

Two hundred sales employees were selected to the sample using random sampling technique

It was selected 200 Sales Employees in travel agents and operators in Sri Lanka as the sample for this study using random sample technique. Unit of Analyses is Individuals. Data was collected through structured questionnaires', interviews emails and telephone conversation. Responses measured using Likert scale method. This scale which is commonly used for questionnaires to rate each question and to apply the technique principle component analysis. Scale has been allocated from 1 to 5 to quantify the results of the study conducting a single cross-sectional study.

Under the principle component analysis, factor analysis was run as the multivariate method. The objective of the factor analysis is to reduction the variables into small number. And designed for interval scale measures.

\subsection{Model}

The model of the factor analysis model can be written algebraically as follows. For the p variables

$$
\mathrm{X}_{\mathrm{i}}=\mathrm{a}_{\mathrm{i}}{ }^{1} \mathrm{~F}_{1}+\mathrm{a}_{\mathrm{i}}{ }^{2} \mathrm{~F}_{2}+\ldots+\mathrm{a}_{\mathrm{i}} \mathrm{F}_{\mathrm{m}}+\mathrm{e}_{\mathrm{i}}
$$

$\mathrm{X} 1, \mathrm{X} 2, \ldots, \mathrm{Xp}$ measured on a sample of $\mathrm{n}$ subjects, $\mathrm{i}$ is the linear combination of $\mathrm{m}$ factors $\mathrm{F} 1, \mathrm{~F} 2, \ldots$, Fm where, as explained above

$\mathrm{m}<\mathrm{p}$.

$\mathrm{X}_{\mathrm{i}}=\mathrm{a}_{\mathrm{i}}{ }^{1} \mathrm{~F}_{1}+\mathrm{a}_{\mathrm{i}}{ }^{2} \mathrm{~F}_{2}+\ldots+\mathrm{a}_{\mathrm{i}}^{\mathrm{m}} \mathrm{F}_{\mathrm{m}}+\mathrm{e}_{\mathrm{i}}$

Where the $a_{i}$ 's are the factor loadings (or scores) for variable $i$ and $e_{i}$ is the part of the variables $X_{i}$ that cannot be 'explained' by the factors.

\section{Descriptive Data Analysis}

From selected sample of 400, 212were females and 106 were males. Among these $48 \%$ of the sample were below the age of 25 and $42 \%$ were within the age limit 36 to 45 years and $8 \%$ were within the age limit 36 to 46 . And $23 \%$ had completed their O/L examination, $14 \%$ had completed their A/L examination. And also 14\% have completed their Bachelor's Degree while 3\% have completed their masters.47\% consisting of monthly income between 45,001 - 70,000. $38 \%$ falls with an income range of 70,001 and above. Income of Rs 30,001 to Rs 45,000 comprises 8\% of the total sample. Respondents falling within income of 15000 - 30000 are $7 \%$ and there aren't any sales employees from the sample who are paid below RS 15000 and below. Amongst the total respondents 61\% recorded as single,29\% married and 10\% 
divorced.38\% of the sample has less than 06 months experience. 34\% has an experience of 01 month to 03 years. 19\% possessed an experience of 07 months to 01 years. $7 \%$ of the sample has an experience period of 03 years 01 month to 05 years. 05 years and 01 month to 7 years of experience counts to $2 \%$ of the sample population.

\subsection{Reliability Test}

Reliability refers to the consistency of the results obtained when the variables are analyzed. It is the extent to which the instrument yields the same results in recurring analyses. Reliability tests available in a research are interobserver reliability, test-retest reliability and internal consistency reliability.

Cronbach's alpha is one of the most popular method for measuring the internal consistency reliability of a group of items. Cronbach's alpha measures how well a set of variables or items measures a single, unidimensional latent construct. Its value ranges from 0 to 1. It will be high when the correlations between the questionnaire items are high and vice versa. According to Malhotra and Dash (2011), to meet the required condition, the standard accepted value should be greater than 0.7 indicator. Also, if any indicator is correlated with the other indicators which have been developed for capturing the domain of the dimensions of the same construct, it was considered as a weak indicator.

\subsection{Test of Normality}

The test of Normality is undertaken to explain the characteristics of the variable of interest (Sekaran \& Bougie, 2014).

\subsection{Validity Test}

Validity a measure accurately represents the concept it claims to measure. There are two kindsof validity. As external validity and internal validity. External validity addresses the ability to apply with confidence the findings of the study to other people and other situations, and ensures that the 'conditions under which the study is carried out are representative of the situations and time to which the results are to apply. Internal validity addresses the reasons for the outcomes of the study, and helps to reduce other, often unanticipated, reasons for these outcomes. There are three approaches of assessing internal validity. They are,

- Content validity

- Criterion related validity

- Construct validity

"Content validity" addresses how well the items developed to operationalize a construct provide an adequate and representative sample of all the items that might measure the construct of interest.

\subsection{Advanced Analysis}

As the first step of the data analysis researcher used exploratory data analysis. Next as the advanced analysis first used the factor analysis and subsequently it was used regression and correlation analysis.

\subsection{Factor Analysis}

Factor Analysis technique is the most widely used technique to measure the unidimensionality (Ziegler \& Hagemann, 2012). Factor analysis refers to the number of statistical procedures used to determine the characteristics that relates to each other variables. Itgives further investigation to the relationships between a wide number of variables and identifying variables that are closely connected together. In this paper it was tried to understand andunidimentionality as the first step of the analysis

\subsection{Unidimensionality of Independent Variables}

Unidemntionality was measured all the indicators which have a factor loading of weak indicators.

\begin{tabular}{|l|c|c|}
\hline \multicolumn{3}{|c|}{ KMO and Bartlett's Test } \\
\hline Kaiser-Meyer-Olkin Measure of Sampling Adequacy. & .894 \\
\hline \multirow{2}{*}{ Bartlett's Test of Sphericity } & Approx. Chi-Square & 1552.498 \\
\cline { 2 - 3 } & $\mathrm{df}$ & 15 \\
\cline { 2 - 3 } & Sig. & .000 \\
\hline
\end{tabular}

Table 1

\subsection{Rotated Component Analyses of the Independent Variable;}

In factor analysis, the factors are rotated towards some variables and away from some other. The reasons behind this is when several factors are extracted, the interpretation of what they represent should be based on the items that load on them (Field, 2009). Thus, if several variables load on several factors, it becomes rather difficult to determine the construct they represent. Thus, factors are rotated towards some variables and away from some.

The rotated component matrix factor analysis for the independent is shown in Table below. The modifications to the main questionnaire was made from this. If the indicators are correlated with two or more indicators and capture the domain of the other dimension in the construct, it is considered as weak. When the test was conducted it was observed that the $3^{\text {rd }}$ and $4^{\text {th }}$ questions from PSQ scale measuring remuneration and the $3^{\text {rd }}$ question of CES scale measuring career 
development were grouped individually. Hence those questions were eliminated as they were weak indicators. The criterion value for acceptance which was 0.5. All the other questions that were remaining had a value above 0.5 and were considered as strong indicators of the rotation component matrix.

\begin{tabular}{|c|c|c|c|c|}
\hline \multicolumn{5}{|c|}{ Rotated Component Matrix } \\
\hline & $\mathbf{1}$ & $\mathbf{2}$ & $\mathbf{3}$ & $\mathbf{4}$ \\
\hline & Component \\
\hline PSQ2 & 0.917 & & & \\
\hline PSQ5 & 0.942 & & & \\
\hline PSQ6 & 0.902 & & & \\
\hline PSQ7 & 0.925 & & & \\
\hline SWWS1 & & 0.955 & & \\
\hline SWWS2 & & 0.957 & & \\
\hline SWWS3 & & 0.914 & & \\
\hline SWWS4 & & 0.926 & & \\
\hline SWWS5 & & 0.945 & & \\
\hline CES1 & & & 0.920 & \\
\hline CES2 & & & 0.919 & \\
\hline CES4 & & & 0.929 & \\
\hline CES5 & & & 0.913 & \\
\hline CES6 & & & 0.926 & \\
\hline WES1 & & & & 0.914 \\
\hline WES2 & & & & 0.932 \\
\hline WES3 & & & & 0.897 \\
\hline WES4 & & & & 0.904 \\
\hline WES5 & & & & 0.907 \\
\hline
\end{tabular}

Table 2

Source: Developed by Researcher

\begin{tabular}{|c|c|}
\hline \multicolumn{2}{|c|}{ Eliminated Questions Are As Follows } \\
\hline \multicolumn{2}{|c|}{ Questions Deleted } \\
\hline Remuneration & PSQ3, PSQ4 \\
\hline Career development & CES3 \\
\hline
\end{tabular}

Table 3

Source: Developed by Researcher

\begin{tabular}{|c|c|}
\hline \multicolumn{2}{|c|}{$\begin{array}{c}\text { Checking The UNI Dimensionality of the Dependent } \\
\text { Variable of Sales Employee Turnover } \\
\text { Component Matrix }\end{array}$} \\
\hline & Component \\
\cline { 2 - 2 } & 1 \\
\hline & .933 \\
\hline TIS1 Re & .930 \\
\hline TIS2 Re & .921 \\
\hline TIS3 Re & .914 \\
\hline TIS4 Re & .934 \\
\hline TIS5 Re & .938 \\
\hline TIS6 Re & \\
\hline
\end{tabular}

Table 4

Source: Developed by the Researcher

The dependent variable which is the "Sales Employee Turnover" falls into one dimension and has a value over 0.5. Hence it was not necessary to eliminate any questions of the dependent variable criterion. 


\subsection{Describe the Latent Variable and Do the Convergent Validity of Pilot Study}

Convergent validity describes the extent to which the latent variable correlates positively with items designed to measure the same construct. There are two criteria to assess whether the outer models (model measurement) is eligible to construct reflective convergent validity, namely loading; Kaiser-Meyer-Olkin (KMO) values of the variables should be greater than 0.7 and a significant p value; Bartlett's test of sphericity should be $(\varangle 0.05>)$ (Hair et al., 2014).

Meanwhile, the reliability was tested by Cronbach alpha values. Good reliability is declared when it has a value of Cronbach alpha>0.60 (Hair et al., 2014).

\begin{tabular}{|c|c|c|c|}
\hline \multicolumn{4}{|c|}{ Convergent Validity Table } \\
\hline Dimensions & KMO & Cronbach's Alpha & $\begin{array}{l}\text { Bartlett's test of Sphericity } \\
\text { and Chi-Squared Value }\end{array}$ \\
\hline Remuneration & 0.906 & .960 & $\begin{array}{c}129.377 \\
\text { Siq } 0.000\end{array}$ \\
\hline Working Environment & 0.889 & .940 & $\begin{array}{c}99.019 \\
\text { Sig } 0.000\end{array}$ \\
\hline Career Development & 0.831 & .956 & $\begin{array}{c}136.410 \\
\text { Sig } 0.000\end{array}$ \\
\hline Job Satisfaction & 0.884 & .964 & $\begin{array}{l}144.326 \\
\text { Sig } 0.000\end{array}$ \\
\hline Sales Employee turnover decision & 0.884 & .956 & $\begin{array}{l}142.048 \\
\text { Sig } 0.000\end{array}$ \\
\hline
\end{tabular}

Table 5

Source: Developed by Researcher

Above tests satisfied the Kaiser-Meyer-Olkin (KMO) value that is greater than 0.5 , the Cronbach alpha is greater than 0.7 and that the chi- squared value of the Bartlett's test of Sphericity is significant at the $5 \%$ level of significance.

\subsection{Measuring Internal Consistency}

A popular method for measuring the internal consistency reliability of a group of items is the Cronbach's alpha. Cronbach's alpha measures how well a set of variables or items measures a single, unidimensional latent construct. Cronbach's alpha value ranges from 0 to 1 and will be high when the correlations between the questionnaire items are high.

\begin{tabular}{|c|c|c|}
\hline \multicolumn{2}{|c|}{ Reliability Test Items for Total Dimensions } \\
\hline & Dimension & $\begin{array}{c}\text { Cronbach's Alpha if Item } \\
\text { Deleted }\end{array}$ \\
\hline Variable & Career Development & .956 \\
\hline & Working Environment & .940 \\
\hline & Job Satisfaction & .993 \\
\hline & Remuneration & .960 \\
\hline Dependent variable & Sales Employee & .956 \\
& Turnover & \\
\hline
\end{tabular}

Table 6

Source: Developed by the Researcher

Above table depicts the Cronbach's alpha values for the independent and dependent variables of the pilot study. According to Malhotra and Dash (2011), to meet the required criterion, the Cronbach's alpha value should be greater than 0.7. Since the value of Cronbach's alpha is greater than 0.7 the measurement scale for all the constructs of the conceptual framework is used for the main study. Since above test are good enough to apply the hypothesis testing next part of the analysis is presented hypothesis testing.

\section{Regression Analysis}

Regression analysis is concerned to fit a best - fit line for dependent and independent variables. In this study it is considered multiple regression model with one dependent variable and four independent variables. Following are described summary results of the regression analysis conducted for individual variables with dependent variables.

The correlation between remuneration and Sales Employee Turnover is significant at 0.01 level as the obtained $p$ value $(.00)$ is lesser than 0.05 . So, it can be concluded that there is significant relationship between remuneration and Sales Employee Turnover. The value of the Pearson correlation is -.976. This indicates that the relationship between the two variables remuneration and Sales Employee Turnover is negative. This means that as remuneration increases, Sales Employee Turnover decreases. And also, it is significant at the value of 0.000 at $5 \%$ level of significance. Further the results of the regression revealed that when the payment is increased by one unit, Sales Employee turnover will decrease will decrease by 0. 979.Similarlyit can be concluded that there is significant relationship between Career Development and Sales Employee Turnover. The value of the Pearson correlation is -983 indicates that the relationship between the two 
variables career Development and Sales Employee Turnover negative. And also,the Pearson Correlation value is -.976 for working environment. As a result of this negative relationship, as working environment conditions increases, Sales Employee turnover will decrease in turn. Furthermore, the correlation between the Sales employee turnover and Job satisfaction is significant at the 0.01 level as the $p$ value $(0.000)$ is less than 0.05 . Therefore, it can be concluded that there is a significant relationship between the Sales employee turnover and Job satisfaction. And there is a negative relationship between Sales employee turnover and Job satisfaction; the Pearson Correlation value is -.981. As a result of this negative relationship, as Job satisfaction working environment conditions increases, Sales Employee turnover will decrease in turn. Having identified that there is a relationship between the independent and dependent variable, a Regression Analysis was conducted, in order to observe the nature of the relationship that exists between the two variables and the results of the Regression Analysis are given below.

\begin{tabular}{|c|c|c|c|c|c|c|}
\hline \multicolumn{7}{|c|}{ Model Building - Job Satisfaction and Sales Employee Turnover } \\
\hline \multicolumn{7}{|c|}{ Coefficients $^{\mathrm{a}}$} \\
\hline \multirow{2}{*}{\multicolumn{2}{|c|}{ Model }} & \multicolumn{2}{|c|}{ Unstandardized Coefficients } & \multirow{2}{*}{$\begin{array}{c}\text { Standardized } \\
\text { Coefficients } \\
\text { Beta }\end{array}$} & \multirow[t]{2}{*}{$\mathrm{t}$} & \multirow[t]{2}{*}{ Sig. } \\
\hline & & $\mathrm{B}$ & Std. Error & & & \\
\hline \multirow[t]{2}{*}{1} & (Constant) & 5.770 & .044 & & 130.210 & .000 \\
\hline & Job Satisfaction & -.926 & .013 & -.981 & -70.331 & .000 \\
\hline
\end{tabular}

a. Dependent Variable: Sale_Turnover_Re

According to table above, the B value of -.926, indicates the value for the Regression equation for forecasting Sales Employee Turnover and the Job Satisfaction and it is significant at the value of 0.000 (5\%). This means that when the Job Satisfaction is increased by one unit of degree, the Sales Employee turnover will reduce by .926.

\begin{tabular}{|c|c|c|c|c|}
\hline \multicolumn{5}{|c|}{ Overall Summary Results of Regression Analysis } \\
\hline \multicolumn{5}{|c|}{ Model Summary } \\
\hline Model & $\mathrm{R}$ & R Square & Adjusted R Square & $\begin{array}{c}\text { Std. Error of the } \\
\text { Estimate }\end{array}$ \\
\hline 1 & $.989 \mathrm{a}$ & .977 & .977 & .20374 \\
\hline
\end{tabular}

Table 8

A. Predictors: (Constant), Job Satisfaction, Work_Enviornment, Career Development, Remuneration

The overall model shows $97.7 \%$ of $\mathrm{R}$ Squared value representing the independent variables. Therefore, the following model was developed by the researcher represent the mediatory variable impact

$\mathrm{Y}=5.770-0.926$ (Job Satisfaction)

\section{Results of the Testing the Hypothesis}

According to the test results of the Pearson Correlation was evident that there is a significant relationship between the two variables as the test was significant at 0.01 level as $p$ value $(0.000)$ was lesser than 0.05 . Also, the correlation value was negative and high (-.976) to categorize the strength of the relationship between the twovariables. Hence it can be concluded that there is a significant high negative relationship between Remuneration and the Sales Employee turnover. Therefore, the tests $\mathrm{KMO}=0.960>0.7$ Cronbach's Alpha $.960>0.60$. There can be seen negative relationship between Remuneration and Employee Turnover. And also,KMO= $0.956>0.7$ Cronbach's Alpha $.956>0.60$, there is a significant positive relationship between career development and employee turnover. When consider the working environment the Pearson correlation value is -.976 indicating negative relationship and $\mathrm{KMO}=0.909>0.7$ Cronbach's Alpha $.960>0.60$. Correlation is significant at 0.01 level as the obtained p value (.00) is lesser than 0.05 .Correlation is significant at 0.01 level as the obtained $p$ value $(.00)$ is lesser than 0.05 .

And there is a significant relationship between Job Satisfaction and Sales Employee. The Pearson correlation value is -.981 indicating negative relationship while $\mathrm{KMO}=0.886>0.7$ Cronbach's Alpha $.969>0.60$

\section{Limitations of the Study}

Though there are more other factors influence on sales employee turnover decision researcher considered only the factors Career Development, Working Environment, Job Satisfaction, Remuneration, Sales Employee Turnover.

\section{Conclusions and Recommendations}

Employee turnover is a problem faced by many of the organizations and is highly researchable topic in the current context. The findings of this research indicated that there is a significant negative relationship between the independent variables Remuneration, Career Development and Working Environment and the dependent variable Sales Employee Turnover. And proves the existence of the mediatory variable Job Satisfaction.

Baron and Kenny (1986) proposed a four-step approach to test the presence of mediatory variable; Coefficient of Remuneration $(\beta=-0.615<\beta=-0.976)$, Working Environment $(\beta=-404<\beta=0.976)$ and Career Development $(\beta=-0.543<\beta=-$ 
0.983) is smaller than the influence on the first requirement. Therefore, it can be shown that the variable of Job Satisfaction mediates partially in the effect of the above three independent variable on Employee turnover.

Hotel Industry is a massive area with many sub sectors. This study was conducted focusing only one segment of Hotel Industry. Similarly, there are more factors that influence sales employee turnover decision such as image of the career opportunity, relationship with supervisors and coworkers' relationships. Hence future researches can be conducted paying attention to the above.

\section{References}

i. Allen, D. Bryant, P and Vardaman, M (2010) 'Retaining Talent: Replacing Misconceptions with Evidence-Based Strategies' Academy of Management Perspectives pp: 48-64

ii. Armstrong, M. 2009, Armstrong's handbook of human resource management practice. 11 ed. London: pp 473

iii. Armstrong, M., (2012),Armstrong's Handbook of Human Resource Management Practice. 12th ed. London: Kogan Page.

iv. Ash, R. A., Dreher, G. F., \& Bretz, R. D., Jr. (1987). Dimensionality and stability of the Pay Satisfaction Questionnaire. Paper presented at the Second Annual Conference of the Society for Industrial and Organizational Psychology, Atlanta, GA.

v. Aydogdu, S. and Asikgil, B. (2011), "An empirical study of the relationship among job satisfaction, organizational commitment and turnover intentions", International Review of Managementand Marketing, Vol. 1 No. 3, pp. 43-53.

vi. Das, B. and Baruah, M. (2013) "Employee Retention: A Review of Literature". Journal of Business and Management 14 (2): pp 8-16 (Online) Available from: http:/ / iosrjournals.org/ iosrjbm/ papers/ Vol14-issue2/ B01420816.pdf

vii. Darcy, C., McCarthy, A., Hill, J. and Grady, G. (2012) Work-life Balance: One Size Fits All? An Exploratory Analysis of the Differential Effects of Career Stage'. European Management Journal, 30(2): pp111-120.

viii. Dwyer, F.R., Schurr, P.H. and Oh, S.J. (1987), “Developing buyer-seller relationships”, Journal of Marketing, Vol. 51, pp.11-27.

ix. Fathima, O. et al, 2012, Employment Security as Moderator on the Effect of Job Security on Worker's Job Satisfaction and Well Being, Asian Social Science,8(0)

x. Gberevbie, D. (2010) 'Strategies for employee recruitment, retention and performance": Dimension of the Federal civil service of Nigeria'. African Journal of Business Management 4(8): pp. 1447-1456

xi. Glebbeek, A. C., and Bax, E. H. (2004). "Is high employee turnover really harmful? An empirical test using company records" Academy of Management Journal, 47(2):pp. 277-286.

xii. Jones, G.R. (1986), "Socialization tactics, self-efficacy and newcomers' adjustments to organizations", Academy of Management Journal, Vol. 29, pp. 262-79.

xiii. Karatepe, O.M. (2012), "The effects of coworker and perceived organizational support on hotel employee outcomes: the moderating role of job embeddedness", Journal of Hospitality \&Tourism Research, Vol. 36 No. 4, pp. 495-516.

xiv. Karas, E. (2017), "Talent management in organizations”, Calitatea, Vol. 18 No. S1, p. 288. t.

xv. Kokt, D. and Ramarumo, R. (2015) "Impact of Organizational Culture on Job Stress and Burnout in Graded Accommodation Establishments in the Free State Province South Africa" International Journal of Contemporary Hospitality Management, 27(6):pp.1198-1213

xvi. Lee, S., Back, J. and Chan, W. (2015) 'Quality of Work Life and Job Satisfaction among Frontline Hotel Employees: A Self-Determination and Need Satisfaction Theory Approach', International Journal of Contemporary Hospitality Management, 27(5):pp.768-789.

Lee, T. H., Gerhart, B., Weller, I. \& Trevor, C. O., 2008. Understanding Voluntary Turnover: Path-Specific Job Satisfaction Effects and the Importance of Unsolicited Job Offers. Academy of Management Journal, 51(4),pp. 651671

xvii. Lee, Y.K., Nam, F.H., Park, D.H. and Lee, K.A. (2006), "What factors influence customer-oriented prosocial behavior of customer-contact employees?", Journal of Services Marketing, Vol. 20No. 4, pp. 251-64.

xviii. Locke, E.A. (1969), “What is job satisfaction?”, Organizational Behavior and Human Performance, Vol. 4 No. 4, pp. 309-336.

xix. Lu, A.C.C. and Gursoy, D. (2013), "Impact of job burnout on satisfaction and turnover intentions: do generational differences matter?", Journal of Hospitality \& Tourism Research, Vol. 2 No. 1.

xx. Maslow, A. H., 1954. Motivation and Personality. Harper \& Row, Publishers, Inc.

xxi. Medina, E, 2012. Job Satisfaction and Employee Turnover Intention: What does Organizational Culture Have To Do with It? M.A. Columbia: Columbia University

xxii. Mehmood N. et al., 2012. A Study of factors affecting job satisfaction. Interdisciplinary Journal of contemporary research in business, 4(6), pp. 678-679

xxiii. Milman, A.(2003), 'Hourly employee retention in small and medium attractions: the central Florida example', Hospitality Management, Vol 22, pp. 17-35

xxiv. Minh-Quang, D., 2013. The Effects of Demographic and Institutional Characteristics on Job Satisfaction of University Faculty in Vietnam. International Journal of Academic Research in Economics and Management Sciences, 2(4), pp 88

xxv. Ongori, H. (2007). 'A review of the literature on employee turnover'. African Journal of Business Management, 1(3): pp. 49-54.

xxvi. Quinlan, C., 2011. Business Research Methods. Hampshire: Thomas Rennie. 
xxvii. Robbins, S.P. and Coulter, M. (1996), Management, Prentice-Hall, Upper

xxviii. Ruchi et al., 2014. Impact of work environment on job satisfaction. International Journal of Scientific and Research Publications, 4(1)

xxix. S.Damayanthi Edirisinghe and Suganya Manuel. "Factors Affecting Sales Employee Turnover in Hotel \& Travel Industry: A Literature Review". IOSR Journal of Humanities and Social Science (IOSR-JHSS). vol. 24 no. 05, 2019, pp. 35-54.DOI: 10.9790/ 0837-2405073554,www.iosrjournals.org

xxx. S.DamayanthiEdirisinghe. "Mismanagement of Human Capital: Adopting a Frame Work, Operationalization and Selecting a Research Design." IOSR Journal of Humanities and Social Science (IOSR-JHSS). vol. 24 no. 06, 2019, pp. 65-71.DOI: 10.9790/ 0837-2406016571,www.iosrjournals.org

xxxi. Samuel, M. O., and Chipunza, C. (2009). "Employee retention and turnover: Using motivational variables as a panacea". African Journal of Business Management, 3(8), 410-415.

xxxii. Sekaran, U. and Bougie, R., 2010. Theoretical framework In theoretical framework and hypothesis development. Research Methods for Business: A Skill Building Approach, p.80.

xxxiii. Tett, R. P., \& Meyer, J. P. (1993). Job Satisfaction, Organizational Commitment, Turnover Intention, and Turnover: Path Analyses Based on Meta-Analytic Findings. Personnel Psychology, 46(2), 259-293

xxxiv. Ton, Z., and Huckman, R. S. (2008). "Managing the impact of employee turnover on performance: The role of process conformance". Organization Science, 19(1): 56-68.

xxxv. Yang, J.T. (2010), "Antecedents and consequences of job satisfaction in the hotel industry", International Journal of Hospitality Management, Vol. 29 No. 4, pp. 609-619.

xxxvi. Zhang, H.Q. and Wu, E. (2004), "Human resources issues facing the hotel and travel industry in China", Journal of Contemporary Hospitality Management, Vol. 16 No. 7, pp. 424-428. 